\title{
PENATAAN KEMBALI KURIKULUM PENDIDIKAN ISLAM
}

\author{
Wagiman Manik, M.Pd.I \\ Program Studi Pendidikan Bahasa Arab STAI As-Sunnah Deli Serdang \\ Jl. Medan-Tg. Morawa, Km. 13, Gang Darmo, Desa Bangun Sari, Kecamatan Tanjung Morawa, \\ Kabupaten Deli Serdang, SUMUT
}

\begin{abstract}
Abstrak:Islam adalah agama yang sempurna dan paripurna yang semua aturan pokok dan prinsip-prinsip besarnya telah baku dari sang pemilik syaria'at Allah swt. oleh karenanya seorang muslim tidak membutuhkan lagi rujukan yang lain dalam mengatur hidup dan kehidupannya selain Alquran dan As-Sunnah sesuai dengan pemahaman salafus shaleh, termasuk dalam masalah pendidikan yang terdapat di dalamnya kurikulum. Oleh karena itu sebuah lembaga/institusi pendidikan Islam harus memiliki sebuah kurikulum yang kuat dan baik, karena kurikulum itu merupakan muatan inti dan ruh dari sebuah pendidikan Islam itu sendiri, untuk mencapai tujuan yang telah ditetapkan.
\end{abstract}

Kata Kunci: Penataan, Kurikulum Pendidikan Islam

\section{Pendahuluan}

Saat ini, ditengarai ada banyak masalah yang terjadi di dalam dunia pendidikan Islam, mulai dari tenaga pendidik, pendanaan, sarana prasarana dan juga kurikulumnya yang tetunya membutuhkan pembinaan, pembenahan dan penataan. Kurukulum dalam sebuah pendidikan adalah ruh dan jantung dari sebuah pendidikan, karnanya kurikulum harus disusun dengan penuh kehati-hatian dan mempertimbangkan dengan matang semua aspek terutama tujuan dari pendidikan Islam itu sendiri, kemudian tujuan dari lembaga/institusi yang menjalankan dan yang melaksanakan kurikulum tersebut, karena komptensi lulusuan dari setiap lembaga pendidikan Islam dipengaruhi oleh sebuah kurikulum yang telah dijalani dan dipelajari sang lulusan. Jika kita memperhatikan dan melihat secara seksama lulusan-lulusan lemabaga pendidikan Islam hari ini, ternyata kurang memiliki kemampuan yang cukup untuk bersaing dengan lulusan dari lembaga lain di luar lembaga pendidikan Islam, di sisi lain akhlak dan moral mereka juga tidak mencermin kan sebagai seorang muslim yang baik, padahal Islam adalah agama yang tinggi dan agama yang sangat menjunjug tinggi moral dan akhlakul karimah.Dengan demikian harus ada pembenahan dari sisi kurikulum dalam sebuah lembaga pendidikan Islam, sehingga setiap peserta didik di dalamnya dapat menjadi pioner dalam hal Iptek dan Imtaq. Penulis pada 
makalah ini akan membahas beberpa poin penting dan krusial yang berkaitan dengan judul di atas yaitu "Penataan Kembali Kurikulum Pendidikan Islam".

\section{Pembahasan}

\section{Pengertian Kurikulum Pendidikan Islam}

Kurikulum menurut bahasa/etimologi adalah tempat berlari yang berasaldari kata latin curir yaitu pelari dan curere yang artinya tempat berlari ${ }^{1}$. Kurikulum juga berasal dari kata curriculaeyang artinya jarak yang harus ditempuh oleh seorang pelari. Makakurikulum adalah jangka waktu pendidikan yang harus ditempuh oleh peserta didik yang bertujuan untuk memperoleh dan mendapatkan ijazah. ${ }^{2}$

Kurikulum dalam pandangan tradisional disebutkan bahwa kurikulum memang hanya rencana pelajaran. Sedangkan Pengertian kurikulum dalam pandangan modern merupakan program pendidikan yang disediakan oleh sekolah yang tidak hanya sebatas bidang studi dan kegiatan belajarnya saja, akan tetapi meliputi segala sesuatu yang dapat mempengaruhi perkembangan dan pembentukan pribadi siswa sesuai dengan tujuan pendidikan yang diharapkan sehingga dapat meningkatkan mutu kehidupannya yang pelaksanaannya tidak hanya di sekolah tetapi juga di luar sekolah. ${ }^{3}$

Atas dasar ini, maka kurikulum itu adalah pengalaman belajar. karena pengalamn belajar yang banyak sangat berpengaruh dalam pendewasaan anak, tidak hanya mempelajari mata pelajaran interaksi sosial di lingkungan sekolah, kerja sama dalam kelompok, interaksi dalam lingkungan fisik, dan lain-lain, juga merupakan pengalaman belajar yang termasuk bagian dari kurikulum itu sendiri. ${ }^{4}$

Selain itu, kurikulum juga dapat dipandang sebagai suatu program pendidikan yang direncanakan dan dilaksanakan untuk mencapai pendidikan ${ }^{5}$. sementara kurikulum menurut M. Arifin adalah seluruh

\footnotetext{
${ }^{1}$ Bukhari Umar, Ilmu Pendidikan Islam (Jakarta: Amzah, 2010), h. 162.

${ }^{2}$ Hery Noer Aly, Ilmu Pendidikan Islam (Jakarta: Logos, 1999), h. 162.

${ }^{3}$ Ramayulis, Ilmu Pendidikan Islam, cet. 5 (Jakarta: Kalam Mulia, 2006), h. 152.

${ }^{4}$ Zakiah Daradjat, dkk., Ilmu Pendidikan Islam (Jakarta: Bumi Aksara, 1996), h. 122. ${ }^{5}$ Ibid.
} 
bahan pelajaran yang harus disajikan dalam proses kependidikan dalam suatu sistem institusional pendidikan. ${ }^{6}$, dan S. Nasution menyatakan, ada beberapa penafsiran lain tentang kurikulum. Diantaranya: Pertama, kurikulum sebagai produk (hasil pengembangan kurikulum), Kedua, kurikulum sebagai hal-hal yang diharapkan akan dipelajari oleh siswa (sikap, keterampilan tertentu), dan Ketiga, kurikulum dipandang sebagai pengalaman siswa. ${ }^{7}$

Umar Muhammad At-Tumi As-Syaibani mendefenisikan kurikulum dalam pendidikan Islam, bahwa kurikulum dikenal dengan kata manhajyang berarti jalan yang terang yang dilalui oleh pendidik bersamaanak didiknya untuk mengembangkan pengetahuan, keterampilan,dan sikap mereka ${ }^{8}$

Sedangkan pengertian kurikulum menurut Undang-Undang Nomor 20 Tahun 2003pasal 1 butir 19 tentang Sistem Pendidikan Nasional yaitu seperangkat rencana dan pengaturan mengenai tujuan, isi dan bahan pelajaran serta cara yang digunakan sebagai pedoman penyelenggaraan kegiatan pembelajaran untuk mencapai tujuan pendidikan tertentu. ${ }^{9}$

Kurikulum pendidikan Islam adalah bahan-bahan pendidikan Islam berupa kegiatan, pengetahuan dan pengalaman yang dengan sengaja dan sistematis diberikan kepada anak didik dalam rangka mencapai tujuan pendidikan Islam. Atau dengan kata lain kurikulum pendidikan Islam adalah semua aktivitasi, pengetahuan dan pengalaman yang dengan sengaja dan secara sistematis diberikan oleh pendidik kepada anak didik dalam rangka untuk mencapai tujuan pendidikan Islam yaitu beribadah kepada Allah swt.

Dengan demikian dapat disimpulkan bahwa Kurikulum Pendidikan Islam (KPI) adalah semua kegiatan yang terjadi di dalam sebuah lembaga pendidikan Islam baik yang terjadi di dalam kelas berupa transfer ilmu

${ }^{6}$ M, Arifin, Ilmu Pendidikan Islam (Jakarta: Bumi Aksara, 1991), h. 183.

${ }^{7}$ S.Nasution, Asas-asas Kurikulum (Jakarta: Bumi Aksara,1994), h. 5-9.

${ }^{8}$ Umar Muhammad at-Taumy As-Syaibani, Falsafah at-Tarbiyah al-Islamiyah (Libiya: Ad-Dar al-‘Arabiyah Lilkitab, 1975), h. 346.

${ }^{9}$ Imas Kurinasih dan Berlin Sani, Implementasi Kurikulum 2013 Konsep dan Penerapan, cet. 2 (Surabaya: Kata Pena, 2014), h. 3. 
pengetahuan kepada peserta didik, maupun di luar kelas berupa kegiatankegiatan untuk menguatkan dan melaksanakan ilmu yang telah mereka dapatkan, yang kesemuanya itu telah tersusun dan terencana denga baik, berdasarkan nilai-nilai Islam yang luhur dari sumber aslinya Alquran dan Sunnah, agar setiap peserta didik kuat dan kokoh secara keilmuan (kognitif), teguh dan mandiri dalam bersikap (afektif), dan istiqomah serta militan dalam beramal (psikomotorik).

\section{Fungsi Kurikulum}

Keberadaan kurikulum sangat penting bagi keberlangsungan proses pendidikan. Oleh karena itu kurikulum memiliki fungsi. Fungsi kurikulum dalam pendidikan Islam dapat ditegaskan sebagai berikut:

a. Sebagai media untuk mencapai tujuan dan untuk menempuh harapan manusia sesuai dengan tujuan yang dicita-citakan;

b. Sebagai pedomandan program yang harus dilakukan oleh subjek dan objek pendidikan;

c. Sebagai Alat untuk menyiapkan pada jenjang sekolah berikutnya, dan penyiapan tenaga kerja bagi yang tidak melanjutkan;

d. Sebagai standardisasi dalam penilaian kriteria keberhasilan suatu proses pendidikan, atau sebagai batasan dari program kegiatan yang akan dijalankan pada caturwulan, semester, maupun pada tingkat pendidikan tertentu. ${ }^{10}$

Abdul Mujib dan Jusuf Muzakir mengatakan bahwa fungsi kurikulum adalah sebagai berikut:

1) Sebagai program studi.

2) Sebagai konten.

3) Sebagai kegiatan terencana,

4) Sebagai hasil belajar,

5) Sebagai reproduksi kultural,

6) Sebagai pengalaman belajar,

7) Sebagai produksi. ${ }^{11}$

${ }^{10}$ Umar, Ilmu... h.172.

${ }^{11}$ Abdul Mujib dan Jusuf Mudzakir. Ilmu Pendidikan Islam (Jakarta: Kencana Prenada Media, 2010), h. 122-123. 
Sementara S. Nasution mengatakan bahwa fungsi kurikulum adalah: Pertama: Kurikulum akan memberikan pengalaman kepada setiap pribadi secara memuaskan, karena kurikulummerupakan proses yang memberikan kebutuhan pertumbuhan dan integritas pribadi seseorang secara bebas dan bertanggung jawab.Kedua: Sebagai alat untuk memengaruhi perubahan sosial dan menciptakan masa depan yang lebih baikbagi masyarakat. Ketiga: Kurikulum berfungsi sebagai proses teknologi untuk mewujudkan tujuan yang dikehendaki oleh pembuatkebijakan.Keempat: Kurikulum berfungsi sebagai alat untuk meningkatkanintelektual atau kecakapan berpikir, dengan caramemperkenalkan para siswa terhadap berbagai macam pelajaran yang terorganisir dengan baik. ${ }^{12}$

Dari beberapa fungsi kurikulum yang telah diuraikan di atas, maka dapat dinyatakan bahwa kurikulum itu barometer dari sukses tidaknya sebuah proses pendidikan, sehingga setiap kurikulum terlebih lagi kurikulum pendidikan Islam (KPI) harus dimaksimalkan fungsinya untuk menjaga kualitas sebuah pendidikan.

\section{Ciri-ciri Kurikulum Pendidikan Islam}

Sesungguhnya kurikulum pendidikanIslam yang memiliki sumber utama dari Alquran dan As-Sunnahmemiliki penekanan pada spiritual tinggi dan akhlak yang mulia. Berikut ini adalah beberapa ciri utama kurikulum pendidikan Islamsebagaimana yang telah dijelsakan oleh AlSyaibani:

a. Kurikulum pendidikan Islam harus menonjolkan mata pelajaran agama dan akhlak. Agama dan akhlak itu harus diambil dari Alquran dan Sunnah sertamencontoh generasi salaf.

b. Kurikulum pendidikan Islam harus memperhatikan pengembangan menyeluruh aspek pribadi siswa, yaitu aspek jasmani, akal dan rohani. Untuk pengembangan menyeluruh ini kurikulum harus berisi mata pelajaran yang banyak, sesuai dengan tujuan pembinaan setiap aspek itu.

${ }^{12}$ S. Nasution,Pengembangan Kurikulum Pendidikan (Bandung: Citra Adirya Bakti, 1991), h. 5 . 
c. Kurikulum pendidikan Islam memperhatikan keseimbangan antara pribadi dan masyarakat, dunia dan akhirat, jasmani, akal dan rohani manusia.

d. Kurikulum pendidikan Islam memperhatikan juga seni, seperti kaligrafi, bangunan dan-lain. Selain itu, memperhatikan juga pendidikan jasmani, latihan militer, teknik, keterampilan dan bahasa asing sekalipun semuanya ini diberikan kepada perseorangan secara efektif berdasarkan bakat, minat dan kebutuhan.

e. Kurikulum pendidikan Islam mempertimbangkan perbedaan kebudayaan yang sering terdapat di tengah manusia karena perbedaan tempat dan juga perbedaan zaman. Kurikulum dirancang sesuai dengan kebudayaan itu. $^{13}$

Adapun ciri-ciri khusus kurikulum pendidikan Islam, yaitu:

a. Dalam kurikulum pendidikan Islam, tujuan utamanya adalah pembinaan anak didik untuk bertauhid. Oleh karena itu, semua sumber yang dirunut berasal dari ajaran Islam;

b. Kurikulum harus disesuaikan dengan fitrah manusia, sebagai makhluk yang memiliki keyakinan kepada Tuhan;

c. Kurikulum yang disajikan merupakan hasil pengujian materi dengan landasan Alquran dan Sunnah.;

d. Mengarahkan minat dan bakat serta meningkatkan kemampuan akliah peserta didik, serta keterampilan yang akan diterapkan dalam kehidupan konkrit;

e. Pembinaan akhlak peserta didik, sehingga pergaulannya tidak keluar dari tuntunan Islam; dan

f. Tidak ada kadaluarsa kurikulum, karena ciri khas kurikulum Islam senantiasa relevan dengan perkembangan zaman, bahkan menjadi filter kemajuan ilmu pengetahuan dan teknologi dalam penerapannya didalam kehidupan masyarakat. ${ }^{14}$

\footnotetext{
${ }^{13}$ As-Syaibani, Falsafah ..., h. 355-371.

${ }^{14}$ Hasan Basri dan Beni Ahmad Saebani, Ilmu Pendidikan Islam (Bandung: Pustaka Setia, 2010), jilid II, h. 182.
} 
Sedangkan menurut Abuddin Nata bahwa ciri-ciri kurikulum pendidikan Islam adalah membina dan mengarahkan potensi akal, jiwa, dan jasmani manusia, sehingga ia memiliki ilmu, akhlaq, dan keterampilan yang semua ini dapat digunakan untuk mendukung tugas pengabdian dan kekhalifahannya, agaria dapat mencapai kebahagiaan hidup di dunia dan di akhirat. ${ }^{15}$

\section{Prinsip-prinsip Kurikukulum Pendidikan Islam}

a. Prinsip yang berorientasi pada tujuan, sehingga tujuan pendidikan yang telah tersusun sebelumnya dapat tercapai. Di samping itu perlu adanya persiapan khusus bagi para penyelenggara pendidikan untuk menetapkan tujuan-tujuan yang harus dicapai oleh setiap peserta didik.

b. Prinsip relevansi. Implikasinya adalah mengusulkan agar kurikulum yang ditetapkan harus dibentuk sedemikian rupa, sehingga tuntutan pendidikan dengan kurikulum tersebut dapat memenuhi jenis dan mutu tenaga kerja yang dibutuhkan masyarakat, serta tuntutan vertical dalam mengemban nilai-nilai ilahi sebagai rahmatan li al-alamin.

c. Prinsip efisiensi dan efektifitas. Implikasinya adalah mengusulkan agar kegiatan kurikulum dapat mendayagunakan waktu, tenaga, biaya, dan sumber-sumber lain secara cermat dan tetap sehingga hasilnya memadai dan memenuhi harapan sera membuahkan hasil sebanyaknya. Islam mengajarkan agar seorang muslim menghargai waktu sebaik-baiknya, karena waktu itu pentig mahal bagi setiap orang, maka Allah swt. sampai bersumpah dengan masa atau waktu, sebagaimana di dalam beberapa surat di dalam Alquranil karim ${ }^{16}$ QS. Al-'Ashr: 1, Adh-Dhuha: 1, Al-lail: 1, Asy-Syams: 1-9.

d. Prinsip fleksibilitas program. Implikasinya adalah kurikulum disusun begitu luwes, sehingga mampu disesuaikan dengan situasi setempat, waktu dan kondisi yang berkembang, tanpa mengembang tujuan pendidikan yang diinginkan. Prinsip ini tidak hanya dilihat dari salah satu faktor, tetapi juga dilihat dari totalitas ekosistem kurikulum, baik yang berkenaan dengan perkembangan peserta didik (kecerdasan, 
kemampuan, dan pengetahuan yang diperolah), metode yang digunakan, fasilitas yang tersedia, serta lingkungan yang mempengaruhinya.

e. Prinsip integritas. Implikasinya adalah mengupayakan kurikulum agar menghasilkan manusia yang seutuhnya, manusia yang mampu mengintegrasikan antara fakultas dzikir dan fakultas fikir, serta manusia yang mampu menyelaraskan kehidupan dunia dan akhirat. Di samping itu, pengupayaan kurikulum tersebut menghasilkan peserta didik yang mampu menguasai ilmu-ilmu qur'ani (din Allah) dan iluilmu kawni (sunnatullah) yang bertujuan untuk mencari ridha Allah swt. Prinsip ini dilakukan dengan cara memadukan semua komponen kurikulum tanpa adanya penggalan satu dengan lainnya.

f. Prinsip kontinuitas (istiqamah). Implikasinya adalah bagaimana susuna kurikulum yang terdiri dari bagian yang berkesinambungan dengan kegiatan-kegiatan kurikulum lainnya, baik secara vertical (penjenjangan, tahapan), maupun secara horizontal.

g. Prinsip sinkronisme. Implikasinya adalah bagaimana suatu kurikulum dapat seirama, searah dan setujuan, serta jangansampai terjadi kegiatan kurikulum lain yang menghambat, berlawanan, atau mematikan kegiatan lain.

h. Prinsip objektivitas. Implikasinya adalah adanya kurikulum tersebut dilakukan melalui tuntutan kebenaran ilmiah yang objektif.

i. Prinsip demokrasi. Implikasinya adalah pelaksanaan kurikulum harus dilakukan secara demokrasi. Artinya, saling mengerti, memahami keadaan dan situasi tiap-tiap subjek dan objek kurikulum. Segala tindakan sebaiknya dilakukan melalui musyawarah untuk mufakat, sehingga kegiatan itu didukung bersama dan apabila terjadi kegagalan maka tidak meyalahkan satu dengan yang lain.

j. Prinsip analisis kegiatan. Prinsip ini mengandung tuntutan agar kurikulum dikonstruksikan melalui proses analisis isi bahan mata pelajaran, serta analisis tingkah laku yang sesuai dengan materi pelajaran. 
k. Prinsip individualisasi. Prinsip kurikulum yang memperhatikan perbedaan pembawaan dan lingkungan pada umumnya yang meliputi seluruh aspek pribadi peserta didik, seperti perbedaan jasmani, watak, inteligensi, bakat, serta kelebihan dan kekurangannya. ${ }^{17}$

Sedangkan menurut Asy-Syaibani, prinsip utama dalam kurikulum pendidikan Islam adalah:Pertama: Berorientasi pada Islam, termasuk ajaran dan nilai-nilainya. Adapun kegiatan kurikulum yang baik berupa falsafah, tujuan, metode, prosedur, cara melakukan, dan hubunganhubungan yang berlaku dilembaga harus berdasarkan Islam, Kedua: Prinsip menyeluruh (syumuliyyah) baik dalam tujuan maupun isi kandungannya, Ketiga: Prinsip keseimbangan (tawazun) antara tujuan dan kandungan kurikulum, Keempat: Prinsip interaksi (ittishaliyyah) antara kebutuhan siswa dan kebutuhan masyarakat.Kelima: Prinsip pemeliharaan (wiqayah) antara perbedaan-perbedaan individu, Keenam: Prinsip perkembangan (tanmiyyah) dan perubahan (taghayyur) seiring dengan tuntutan yang ada dengan tidak mengabaikan nilai-nilai absolut ilahiyyah, Ketujuh: Prinsip integritas (muwahhadah) antara mata pelajaran, pengalaman, dan aktivitas kurikulum dengan kebutuhan peserta didik, masyarakat dan tuntutan zaman serta tempat peserta didik berada. ${ }^{18}$

\section{Isi Kurikulum Pendidikan Islam}

Al-Imamal-Ghazali tentang kurikulum dapat dipahami dari pandangannya mengenai ilmu pengetahuan. Ia membagi ilmu pengetahuan kepada yang terlarang dan yang wajib dipelajari oleh anak didik menjadi tiga kelpmpok yaitu :

a. Ilmu yang tercela, banyak atau sedikit. Ilmu ini tidak ada manfaatnya bagi manusia di dunia dan di akhirat, misalnya ilmu sihir, nujum dan ilmu perdukunan. Bila ilmu ini dipelajari akan membawa mudarat dan akan meragukan terhadap kebenaran adanya tuhan. Oleh karena itu ilmu ini harus di jauhi.

\footnotetext{
${ }^{17}$ Umar, Ilmu ..., h, 167-170.

${ }^{18}$ As-Syaibani, Falsafah...h.377-379.
} 
b. Ilmu yang terpuji, banyak atau sedikit. Misalnya ilmu tauhid dan ilmu agama. Ilmu ini bila dipelajari akan membawa seseorang kepada jiwa yang suci, bersih dari kerendahan dan keburukan serta dapat mendekatkan diri kepada Allah swt.

c. Ilmu yang terpuji pada taraf tertentu, yang tidak boleh diperdalam, karena ilmu ini dapat membawa kegoncangan iman dan ilhad (meniadakan Tuhan) seperti filsafat.

Maka dari ketiga kelompok ilmu tersebut, Al-Imam al-Ghazali membagi lagi ilmu tersebut menjadi dua kelompok, ilmu dilihat dari segi kepentingannya, yaitu:

1) Ilmu yang wajib yang diketahui oleh semua orang, yaitu ilmu agama, ilmu yang bersumber pada kitab Allah.

2) Ilmu yang hukummempelajarinya fardhu kifayah, yaitu ilmu yang digunakan untuk memudahkan urusan duniawi seperti ilmu hitung, ilmu kedokteran, ilmu teknik,ilmu pertanian dan industri. ${ }^{19}$

Sedangkan Abdul Mujib dan Jusuf Mudzakir mengambil isi Kurikulum Pendidikan Islam yang berpijak pada Alquran di dalam surat Fushshilat ayat 53.

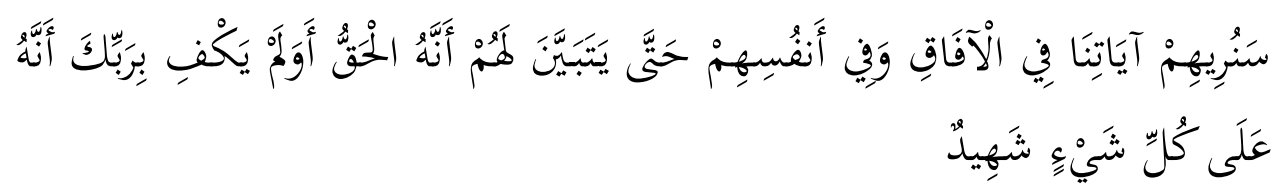

Kami akan memperlihatkan kepada mereka tanda-tanda (kekuasaan) Kami di segenap ufuk dan pada diri mereka sendiri, sehingga jelaslah bagi mereka bahwa al-Qur'an itu benar.Dan apakah Rabbmu tidak cukup (bagi kamu) bahwa sesungguhnya Dia menyaksikan segala sesuatu. ${ }^{20}$

Dalam ayat ini terkandung tiga isi Kurikulum Pendidikan Islam, yaitu: Pertama: Isi kurikulum yang berorientasi pada "ketuhanan" Ilmu ini meliputi ilmu kalam, fiqh, akhlaq/tasawuf, ilmu-ilmu tentang Alquran dan lain- lain, Kedua: Isi kurikulum yang berorientasi pada "kemanusiaan". Ilmu ini berkaitan dengan perilaku manusia, baik sebagai makhluk individu maupun sosial, berbudaya dan berakal.Ilmu ini meliputi ilmu sejarah, politik, bahasa, filsafat, psikologi dan lain-lain.Ketiga: Isi

\footnotetext{
${ }^{19}$ Ahmad Syar'i, filsafat Pendidikan Islam(Jakarta: Pustaka Firdaus,2005),h.166.

${ }^{20}$ QS. Fussilat $/ 41: 53$
} 
kurikulum yang berorientasi pada"kealaman". Ilmu ini berkaitan dengan alam semesta, seperti : ilmu fisika, kimia, pertanian, perikanan, biologi danlain-lain. $^{21}$

\section{Medesain kurikulum pendidikan Islam.}

Mendesain kurikulum berarti menyusun rancangan atau menyusun model kurikulum sesuai dengan misi dan visi sekolah ${ }^{22}$, di dalam sebuah kurikulum terdapat beberapa komponen yang tidak boleh diabaikan keberadaannya, komponen-komponen itu adalah:Pertama: Tujuan, Kedua: Isi, Ketiga: Metode atau Proses Pembelajaran, Keempat: Evaluasi. ${ }^{23}$, dan dalam mendesain kurikulum pendidikan Islam harus mendasarkan kepada komponen-komponen kurikulum yang telah di atas.

Dengan demikian agar penyusunan atau perumusan sebuahkurikulum pendidikan Islam (KPI) menjadi baik dan mantap perlu memperhatikan prinsip-prinsip kurikulum, dan di dalam pembuatannya perlu membentuk tim perumus kurikulum, yang kemudian kurikulum itu dirumuskan melalui workshop atau yang lainnya yang dipimpin oleh seorang pakar atau lebih dalam bidang kurikulum. Menurut hemat penulis untuk merumuskan tujuan kurikulum harus mempertimbangkan standar kompetensis lulusan (SKL) dari sebuah lembaga pendidikan Islam sebagai tujuan akhir, dan tujuan antara dari masing-masing mata pelajaran yang terdapat dalam kurikulum, agar peserta didik sampai pada tujuan akhir yang telah ditentukan

Terkait dengan Isi kurikulum harus tetap mengacu kepada tujuan akhir atau SKL, dengan tetap memperhatikan perkembangan kemampuan siswa yang bersangkutan dankebutuhan individu serta masyarakatnya menurut tempat dan waktu. Sedangkan metode yang terbaik menurut penulis adalah, metode yang paling sesuai atau yang paling layak, dan

${ }^{21}$ Abdul Mujib dan Jusuf Mudzakir, Ilmu Pendidikan Islam (Jakarta: Kencana Prenada Media, 2010), h. 153.

${ }^{22}$ Wina Sanjaya, Kurikulum dan Pembelajaran Teori dan Praktik Pengembangan Kurikulum Tingkat Satuan Pendidikan (Jakarta: Kencana Prenata Media Group, 2010), h. 63.

${ }^{23}$ Ahmad Tafsir, Ilmu Pendidikan Islam (Bandung: Remaja Rosdakarya, 2013), h. 83. 
untuk evalusi menurut penulis ada 2 (dua), pertama mengevaluasi kurikulum secara keseluruhan dan komprehensif yang dilakukan secara berkala minimal setiap 2 (dua) tahun sekali, atau dengan bahasa lain peninjauan ulang kurikulum, kedua, mengevaluasi hasil belajar siswa dari kurikulum yang telah di ajarkan kepada mereka, baik melalui tugas mandiri, uts dan uas yang dilakukan secara rutin dalam waktu yang telah ditetapkan.

Menurut penulis sesungguhnyaperhari ini ada5 (lima) hal yang harus dibenahi terkait dengan Kurikulum Pendidikan Islam (KPI) sebagai bentuk penataannya, yaitu:

\section{Konten (Isi Kurikulum)}

Konten atau isi kurikulum yang ada pada hari ini, perlu untuk dikaji dan dibenahi di semua jenjang/tingkat pendidikan mulai tingkat Sekolah Dasar (SD) sampai dengan perguruan tinggi (PT) dari urusan akidah, ibadah dan mua'amalah sesuai dengan porsinya masing-masnig. Sebagai contoh di tingkat sekolah dasar sudah seharusnya di dalam materi akidah dimasukkan pembahasan tentang rukun Iman, Islam dan Ihsan, terutama tentang ma'na, rukun, syarat, konsekwensi dan pembatal شهادة لا إله إلا الهه وشهادة محمد ) (رسول الله), serta dijelaskan juga tentang keutamaan tauhid dan bahaya syirik.

Sedangkan dari sisi ibadah harus di ajarakan dengan baik dan benar tentang sifat whudu' Nabi saw., sifat shalat Nabi saw., sifat puasa Nabi saw. dan lain-lain, termasuk tata cara mandi wajib untuk tingkat Sekolah Dasar (SD) terutama yang sudah duduk di kelas 5 (lima) dan 6 (enam), karena pada usia itu sebagian anak-anak yang berada di Sekolah Dasar teruma perempuan sudah ada yang baligh (mukallafah). Dan adapun dalam hal mua'amalah maka semenjak sekarang peserta didik mulai tingkat Sekolah Dasar (SD) sampai dengan tingkat Sekolah Menengah Atas atau yang sederajat sudah mulai diajarakan bagaimana cara bergaul dengan orang-orang yang di luar Islam, cara berdagang ala Nabi saw,. bahaya riba dan lain-lain. 


\section{Waktu}

Sudah menjadi takdir manusia bahwa suatu saat nanti ia akan pindah rumah dari atas tanah menuju rumahnya yang ada di bawah tanah melalui proses kematian, untuk mempertanggungjawabkan semua perbuatannya selama ia hidup di duania, maka hendaknya setiap orang harus mempersiapakan amalan terbaiknya untuk mendampinginya kelak di dalam kuburan, dan tidak ada jalan lain untukmempersiapakan amalan terbaik itu melainkan dengan ilmu agama yang baik dan benar, dan untuk mendapatkan ilmu agama yang baik dan benar harus kita mengorbankan waktu yang banyak dan terbaik kita, karnanya menurut penulis, jika hari ini alokasi waktu yang disediakan untuk materi PAI hanya 2 (dua) SKS, atau 4 SKS perpekan maka ini masih jauh dari kata cukup, karena ilmu agama ini adalah ilmu yang selalu dan setiap saat kita pakai dan kita gunakan, berbeda dengan ilmu-ilmu lain yang bukan agama terkadang kita tidak pernah menggunakannnya atau jarang sekali menggunakannya, oleh karena itu perlu penataan KPI dari alokasi waktu, sehingga meteri PAI dapat dipahami dengan baik oleh peserta didik sabagai acuan mereka dalam beramal.

\section{Tenaga pengajar kurikulum}

Setiap pendidik yang menyampaikan materi pendidikan agama Islam kepada peserta didiknya, harus mampu menjadi tauladan di hadapan anak didiknya, dan untuk bisa menjadi tauladan di hadapan perserta didik seorang pendidik harus ikhlas dan tulus dalam menyampaikan materinya kepada anak didiknya, dan ia selalu berusaha untuk menselarkan antara perkataan dan perbuatannya, sehingga jika ia menganjurkan peserta didiknya untuk shalat berjama'ah di masjid, maka ia adalah orang yang rajin melaksanakan shalat berjama'ah di masjid, dan ketika ia melarang anak didiknya agar tidak merokok, maka ia adalah orang yang jauh dari rokok, dan seterusnya-seterusnya, maka dengan demikian setiap materi yang diajarkan oleh seorang pendidik, tidak hanya bercokol dan berkutat pada tataran ilmu (kognitifnya) saja, tetapi dapat 
terlihat dan diturunkan di dalam sikap (afektinya) dan pengamalannya (psikomotoriknya),

Dengan demikian sudah sapatutnya dan seharusnya dalam rangka meneladani Nabi Muhammad saw. yang sukses dalam mendidik para sahabatnya, maka setiap pengajar atau pendidik memiliki kompetensi (Abstrak/A) yang cukup dalam bidangnya dan memiliki komitmen (K) yang kuat, dan jangan menjadi orang yang memiliki kompotensi tetapi tidak memiliki komitmen, atau memiliki komitmen tetapi tidak memiliki kompetensi yang cukup, atau yang paling parah lagi adalah ada tenaga pendidik/pengajar yang tidak memiliki kompetensi dalam bidangnya dan tidak pula memiliki komitmen, na'uzu billah min zalik. Sebagaimana dalam table berikut ini.

\begin{tabular}{|c|c|c|c|c|c|}
\hline \multirow{2}{*}{ NO } & \multirow{2}{*}{ Kode } & \multicolumn{4}{|c|}{ Kriteria Pendidik } \\
\cline { 3 - 6 } & & Sangat baik & Baik & Cukup & Buruk \\
\hline 1 & AK+ & $\sqrt{ }$ & - & - & - \\
\hline 2 & A+K- & - & $\checkmark$ & - & - \\
\hline 3 & A-K+ & - & - & $\checkmark$ & - \\
\hline 4 & A-K- & - & - & - & $\checkmark$ \\
\hline
\end{tabular}

\section{Metode}

Setiap pendidik yang menyampaikan materi pendidikan agama Islam kepada peserta didiknya, tidak lagi mencukupkan metodenya hanya pada hafalan saja, tetapi harus menggabungkan metode hafalan dengan metode diskusi, tanya jawab, seminar dan dan lain-lain agar peserta didik memiliki pemahaman yang kuat dan daya analisis yang tinggi terhadap materi agama Islam yang disampaikan kepadanya. Maka dengan demikian pemahaman peserta didik tidak kaku, dan dapat merespon perkembangan zaman dengan tetap Istiqamah dengan ajaran dan nilainilai agamanya.

\section{Paradigma}

Ada kesan selama ini bahwa kurikulum pendidikan Islam itu tidak mampu menjadikan seseorang itu hebat dan terkenal, padahal kurikulum pendidikan Islam yang bersumber kepada Alquran dan Sunnah dan keduanya ini adalah darah dan daging modernisasi pendidikan yang 
dengannya seseorang menjadi hebat dan terkenal, dan sebab kurikulum ini pula yang menjadikan seseorang itu mengerti dan paham bagaimana cara ibadah kepada Allah swt. begitu juga dengan akhlak, hak-hak orang tua, dan menjadikan seseorang itu tidak sombong dan tidak angkuh dan lain sebagainya.

Kemudian saat ini pemerintah telah membebankan kepada Kementerian Agama, bahwa kementerian ini adalah Penjaga dan Pengawal moral bangsa, bagaimana hal ini bisa terjadi dan terlaksana, jika masih ada pandangan yang miring bahkan cenderung memarjinalkan kurikulum pendidikan Islam itu sendiri. Oleh karena itu harus disadari oleh semua pihak, bahwa kurikulum pendidikan Islam adalah bagian terpenting dari kurikulum pendidikan nasional Indonesia, atau dengan kata lain bahwa kurikulum pendidikan Islam telah inklud di dalam kurikulum pendidikan nasional Indonesia sabagaimana dalam Undangundang. Dengan demikian posisi kurikulum pendidikan Isalm harus ditinggikan dan dinomor satukan dengan cara, pertama: Mata pelajaran agama masuk ke dalam Ujian Nasional jika masih ada kelak, kedua: Akhlakul karimah sebagai realisasi dari nilai-nilai ajaran agama menjadi penentu utama untuk juara kelas, dan lain-lain.

\section{Contoh Kurikulum Pendidikan Islam di SMA Padangsidempuan}

\section{a. Identitas Sekolah}

Nama Sekolah

Alamat

Jumlah siswa

Jumlah Guru PAI

Alokasi waktu
: SMA Negeri 5

: Padangsidempuan Sumut

: 550 Orang

: 2 (dua) Orang

: 3 sks kelas X, \& 2 sks untuk XI dan XII

\section{b. Isi Kurikulum PAI TA. 2017-2018}

Jumlah Kelas

: 18 Kelas, dengan perincian:

1) Kelas X Sebanyak 7 kelas

2) Kelas XI \& XII sebanyak 11 kelas

Materi PAI

: Untuk kelas X SMS Ganjil

1) Iman kepada Allah swt.

2) Kewajiban menutup aurat dengan busana muslimah 
3) Keutamaan sifat jujur

4) Sumber-sumber hukum Islam

5) Sejarah dakwah Nabi Muhammad saw.

6) Prilaku terpuji. Sedangkan untuk SMS genap adalah sebagi berikut:

1) Iman kepada Malaikat

2) Haji, Zakat dan Waqaf

3) Dakwah Nabi di Madinah

4) Nikmat mencari ilmu dan indahnya berbagi ilmu pengetahun

5) Menjaga martabat manusia dengan menjauhi pergaulan bebas

\section{c. Penataan Kurikulum PAI}

Dari uraian meteri kurikulum PAI yang ada di SMA Negeri 5 Padangsidempuan di atas, maka dapat saya simpulkan bahwa ada beberapa hal yang harus ditata dan dibenahi:

1) Dari sisi waktu, menurut hemat penulis jika hanya 3 sks setiap pekan dengan estimasi waktu 3 x 45 menit, belum cukup untuk memberikan pemahaman yang benar tentang materi yang dibahas, maka perlu untuk di tambah 1 sks lagi sehingga mejadi 4 sks per pekan.

2) Dari sisi jumlah guru, dengan jumlah kelas yang besar sampai 18 kelas, maka setidaknya dibtuhkan 3 orang guru untuk PAI.

3) Dari sisi sub-sub judul yang ditawarkan disetiap semesternya, maka perlu untuk merujuk dan mempertimbangkan hal-hal yang dibutuhkan oleh seorang anak dengan usia mereka yang seperti itu.

4) Dari sisi penilian harus mempertimbangkan ketiga sisi yang ada atau nilai totalitas dari kognitif, afektif dan psikomotorik.

\section{Penutup}

Kurikulum pendidikan Islam (KPI) merupakan salah faktor yang paling terpenting dalam sebuah lembaga pendidikan, karena kurikulm pendidikan Islam adalah semua kegiatan yang terjadi di dalam sebuah lembaga pendidikan Islam baik yang terjadi di dalam kelas berupa transfer 
ilmu pengetahuan kepada peserta didik, maupun di luar kelas berupa kegiatan-kegiatan untuk menguatkan dan melaksanakan ilmu yang telah mereka dapatkan, yang kesemuanya itu telah tersusun dan terencana denga baik, berdasarkan nilai-nilai Islam yang luhur dari Alquran dan Sunnah, agar setiap pesesta didik kuat dan kokoh secara keilmuan (kognitif), teguh dan mandiri dalam bersikap (afektif), dan istiqomah serta militan dalam beramal (psikomotorik).

Kemudian untuk membentuk pesesta didik yang kuat dan kokoh secara keilmuan (kognitif), teguh dan mandiri dalam bersikap (afektif), dan istiqomah serta militan dalam beramal (psikomotorik), maka perlu menyiapkan dan menyusun sebuah kurikulum yang baik, yang dengannya dapat mencapai tujuan dan cita-cita yang diinginkan. Namun harus disadari bahwa kurikulum pendidikan Islam senantiasa memerlukan pembenahan dan penataan serta juga pembelaan di tengah gencarnya arus sekulerisasi dan westernisasi, dan juga terkadang di tunggangi oleh kepentigan penguasa atau politik pendidikan. 


\section{Pustaka Acuan}

Alquran al-Karim

Aly, Hery Noer, Ilmu Pendidikan Islam, Jakarta: Logos, 1999

Arifin, M, Ilmu Pendidikan Islam (Jakarta: Bumi Aksara, 1991), h. 183.

As-Syaibani, Umar Muhammad at-Taumy, Falsafah at-Tarbiyah al-Islamiyah, Libiya: Ad-Dar al-'Arabiyah Lilkitab, 1975

Basri, Hasan dan Saebani, Beni Ahmad, Ilmu Pendidikan Islam, Bandung: Pustaka Setia, 2010

Daradjat, Zakiah, dkk., Ilmu Pendidikan Islam, Jakarta: Bumi Aksara, 1996

Kurinasih, Imas dan Sani, Berlin, Implementasi Kurikulum 2013 Konsep dan Penerapan, cet. 2, Surabaya: Kata Pena, 2014

Mujib, Abdul dan Mudzakir, Jusuf. Ilmu Pendidikan Islam, Jakarta: Kencana Prenada Media, 2010

Nata, Abuddin, Filsafat Pendidikan Islam, Jakarta: Gaya Media Pratama, 2005

Nasution, S., Asas-asas Kurikulum (Jakarta: Bumi Aksara,1994), h. 5-9 Bakti, 1991 Pengembangan Kurikulum Pendidikan, Bandung: Citra Adirya

Ramayulis, Ilmu Pendidikan Islam, cet. 5 (Jakarta: Kalam Mulia, 2006), h. 152

Sanjaya, Wina, Kurikulum dan Pembelajaran Teori dan Praktik Pengembangan Kurikulum Tingkat Satuan Pendidikan, Jakarta: Kencana Prenata Media Group, 2010

Syar'i, Ahmad, filsafat Pendidikan Islam, Jakarta: Pustaka Firdaus,2005

Tafsir, Ahmad, Ilmu Pendidikan Islam, Bandung: Remaja Rosdakarya, 2013

Umar, Bukhari, Ilmu Pendidikan Islam, Jakarta: Amzah, 2010 